\title{
作業者の操作性を考慮した着脱式姿勢可変型直接教示装置の開発*
}

鄭 聖 喜*1, 中 坊 嘉 宏*2
尾暮 拓 也光, 山 田 陽 滋*3

\section{Development of an Attachable and Pose-changable Direct Teaching Device Considering Operability}

\author{
Seonghee JEONG ${ }^{* 4}$, Yoshihiro NAKABO, \\ Takuya OGURE and Yoji YAMADA \\ ${ }^{* 4}$ Department of Electro-Mechanical Engineering, Osaka Electro-Communication University, \\ 18-8 Hatsu-cho, Neyagawa-shi, Osaka, 572-8530 Japan
}

\begin{abstract}
This paper proposes a direct teaching device for a multi-D.O.F industrial manipulator considering a worker's safety and operability. The proposed device named as APDT, Attachable and Posechangable Direct Teaching device, in composed of a pose adjusting part and a teaching handle part. It is capable of easy mounting/unmouting on a robot end-effector and of adjusting a pose of a teaching handle freely without consideration of the pose of an end-effector. By using APDT, a worker is able to perform a direct teaching task for a multi-D,O.F manipulator in a comforable posture even in case of teaching in the large pose change of the end-effector by adjusting the pose of the teaching handle. This will bring the reduction of load of a worker in a long time teaching task. Consequently, the reduction of risk due to inappropriate work posture and the improvement of task efficiency is expected. Simple direct teaching task using APDT with SP02, cell-production robot, was conducted to confirm the effectiveness of APDT.
\end{abstract}

Key Words: Direct Teaching Device, Pose-Changable, Operability, Safety

\section{1.はじめに}

1.1 開発背景＼cjkstart近年, 製造業分野では少子高龄化 や熟練者不足等による生産性の悪化，製品品質の低下 等の問題が懸念され，その対策の一つとして，ロボッ トシステムの製造現場への導入が積極的に進められて いる. 多自由度マニピュレータは, 自動車生産ライン や造船現場，情報家電製造ライン等において，溶接や 塗装, 組み立て, 検査等の作業に幅広く用いられる代 表的な産業用ロボットシステムである. 多自由度マニ ピュレータを用いて作業を行うためには，通常，「教示 作業」と呼ばれるロボットの作業動作を予め「教える」 工程が必要となる。これまで, 教示時間の短縮, 教示 精度の向上等教示作業の効率改善を目的とした教示方 法がいくつか提案されており ${ }^{(1)(2)(3)}$, 直接教示(ダイレ クトティーチ)もその代表的な方法である(4). 直接教示は，ロボットの先端に教示作業者(以下，作

* 原稿受付 2010 年 7 月 13 日.

*1 正員, 大阪電気通信大学電子機械工学科(丞 572-8530 誛屋 川市初町 18-8).

*2 (独) 産業技術総合研究所知能システム研究部門 (\$305-8568 つくば市梅園 1-1-1).

*3 正員, 名古屋大学工学研究科 (更 464-8603 名古屋市千種区 不老町).

E-mail : s-jeong@isc.osakac.ac.jp
業者)の力を检出する直接教示装置を設け，作業者の 操作力に追従するようロボットを制御して動作を教え 込む教示方法である。この方法は，作業者が直接に多 自由度マニピュレータの先端を把持して操作を行うの で, ペンダントや GUI 等従来の方法でのロボット動作 と作業者の操作感覚のズレによる教示作業効率の低下 を防ぐことができ，複雑な教示作業の場合でも効率よ く教示作業を行うことが可能である．直接教示では作 業者がロボット先端の教示ハンドルを直接把持して教 示を行うため，作業者の教示姿勢を含む「操作性」を 十分に考虑しなければならない。操作性の低下は作業 効率及び作業精度への影嚮のみならず，作業者の精神 的・肉体的障害を引き起こす要因でもある。したがっ て, 作業性 (効率や精度) と安全性 (精神的- 身体的障 がい)を考虑した操作性を持つ教示システムの構築は 重要な課題であると言える。

1.2 関連研究 産業用多自由度マニピュレータ 用の直接教示装置としては，力センサ (又はオブザーバ 等により力を検出する手段) が手首に内蔵されている 内蔵型と，力センサを含む教示ハンドル装置がロボッ 卜本体と独立に構成される外装型に別けられる。内蔵 
型は力制御を要する作業を行うマニピュレータに一般 的に用いられるものであり ${ }^{(6)}$ ，外装型は力制御を必要 としない PTP(Point To Point) や CP(Continuous Path) 制御等に用いられるマニピュレータに導入される. 本 研究では, 組み立て, 溶接, 塗装等の作業において, 主に PTPや CP 制御されるマニピュレータ用の外装型 直接教示システムを対象とする.

これまでの外装型直接教示装置の場合, 作業者が把 持する教示ハンドルは姿勢の調整ができない固定式 ${ }^{(7)}$ が殆どであった。姿勢の調整が可能な教示ハンドルを 持つ直接教示装置も提案されているが(8), 教示ハンド ルの取り付け位置が決められており，ハンドルの姿勢 調整角には限界がある.このような従来型教示ハンド ルを用いてマニピュレータ先端の大きな姿勢変化が必 要な教示作業を行う場合, 作業者は手首や肘等の関節 を大きく曲げる不自然な姿勢で教示作業を実行せざる を得ない. 長時間に及ぶ無理な姿勢での作業は, 精神 的・肉体的に疲労が蓄積されやすく, 結果的に, 注意 力の低下による操作ミスや無理な姿勢による発病等安 全性を大きく低下する要因になると指摘されている ${ }^{(9)}$. さらに, 生産性の観点からみると, 集中力の低下や不 自然な姿勢での作業は作業効率や作業品賀の低下を招 く要因としても考えられる.

1.3 開発目標 本研究は, 生産現場での直接教示 作業において，作業者の不適切な教示姿勢に起因する リスクの低減及び教示作業効率の向上が実現可能な操 作性の高い直接教示システムの開発を最終目標とする.

本稿では，本質安全設計の非制御手段 ${ }^{(5)}$ である人間 工学原則を考虑した操作性を有する「着脱式姿勢調整 型直接教示䒾置」を提案する. 同装置は, 教示ハンド ルを必要な時に簡単に着脱でき,マニピュレータ先端 姿勢が大きく变化する教示作業の場合でも, 教示ハン ドルの姿勢調整により作業者が無理なく教示ハンドル 操作が可能な特改を持つ.さらに, 教示力やハンドル 姿勢検出センサをハンドルに内装したモジュール化に より， 1 台の教示モジュールで复数のロボットの教示 が実現でき，設備投資等のコストダウンが期待できる. 本稿では, 提案する装置の着脱及び管勢調整機構, 姿 勢調整時の教示アルゴリズムを中心に述べ, 最後に, 簡単な直接教示作業実験を通して, 同装置の教示作業 遂行性能の検証及び教示作業時の作業者の姿勢につい ての検討を行う。

以降， 2 章では, 開発した着脱式姿勢可変型直接教 示装置のメカニズム及び基本動作原理を，3 章では, 教ホハンドル部の姿勢計測方法及び計測精度評価結果 について述べる. 最後に, 4 章では, 本教示装置を用

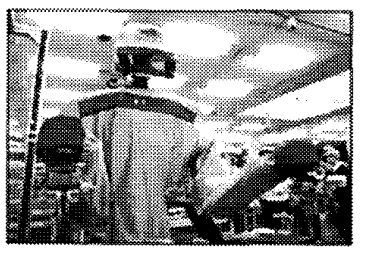

(a) $\mathrm{SPO} 2$

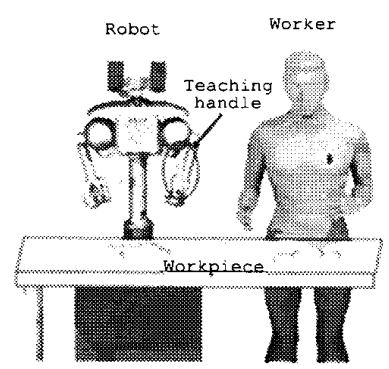

(b) Cell workspace
Fig. 1 SP02 and a cell workspace

いた簡単な直接教示及び再生実験を実施し, 装置の教 示性能及び教示作業時の作業者の教示姿勢の簡易評価 結果について述べる.

\section{2. 着脱式姿勢可変型直接教示装置}

2.1 開発コンセプト 本研究で開発する直接教 示装置は, 図1(a)に示す上体ヒューマノイドロボット $\mathrm{SP} 02^{(10)}$ のマニピュレータへの搭載を前提とする. SP02 は汹 1(b)のようなセル生産現場において, PTP 制御 による Pick and Place 作業の実行を目的に開発された ロボットであり, 各6 自由度の双腕を持つ. 教示作業 を実行する際に，作業者はSP02 の隣でマニピュレー 夕の先端に直接教示装置を装着し，教示ハンドルを把 持・操作することで実際の作業工程を教え込むことに なる. 開発する直接教示装置の機構設計におけるコン セプトを以下に示す。

1. ロボットの手先先端の姿勢に係わらず，作業者が 安定な姿勢で教示ハンドルを簡単に着脱できる 機構.

2. 教示ハンドルを手先先端へ装着後, 作業者が作業 しやすいようにその姿勢調整が自由にできる機構。 (1)により, チョコ停等のロボット停止時の手先先端姿 勢に係わらず, 作業者が安定な姿勢で迅速に教示作業 を実施した後，再び通常運転へ復归することが可能な ので, 結果的に生産性の向上が期待できる。 また，(2) により, 手先先端の姿勢が大きく变わる教示作業時に, 作業者の手首や肘, 腰関節への姿勢負担が軽減され, 教示作業の安全性及び作業効率の向上が期待できる. さらに, 本稿での開発段階には含まれていないが, 最 終開発目標として, ロボットの追従動作制御部へ教示 情報 (教示力, ハンドル姿勢) を提供する独立した教示 情報生成部と上記機構を組合せ, 直接教示モジュール を構成することも可能である(11).これにより，1 台の 教示モジュールで複数のロボットの教示が実現でき， 設備投筫等のコストダウンが期待できる. 


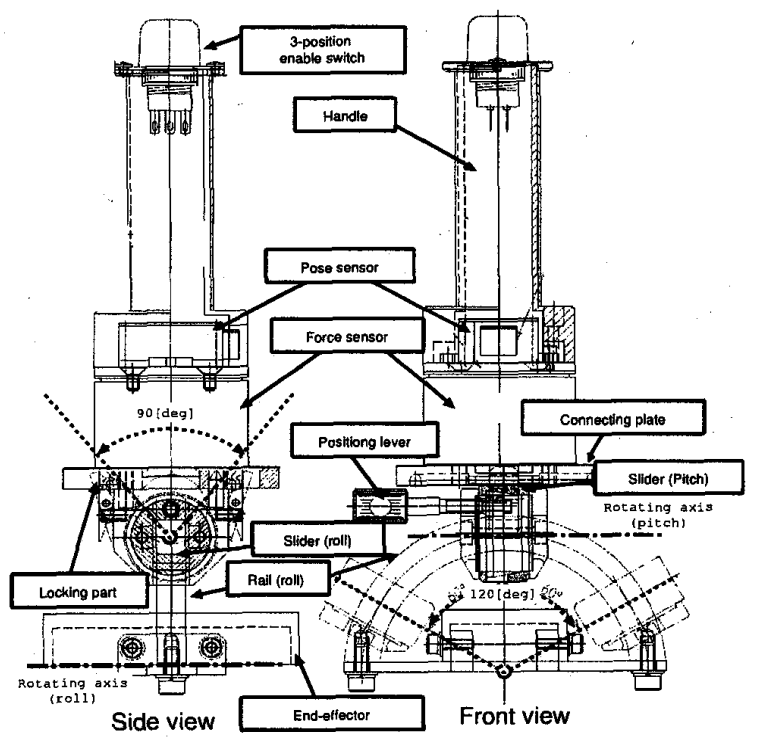

(a) Design

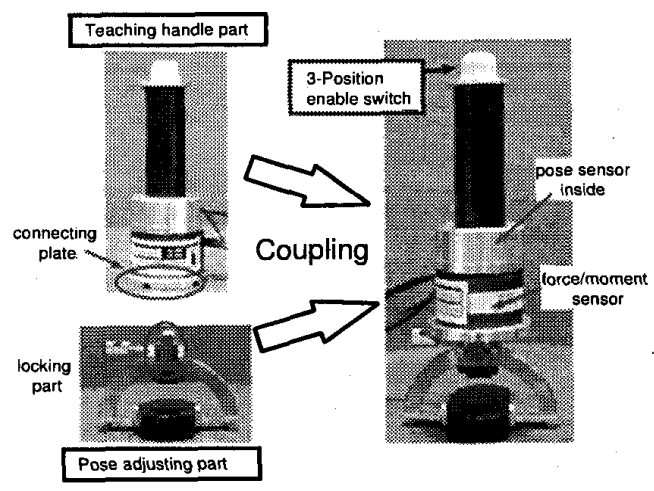

(b) Appearance

Fig. 2 Prototype of Attachable and Pose-changable Direct Teaching device

\section{2 着脱式姿勢可変型直接教示装置 汹 2 に前述} のコンセプトを基に開発した着脱式姿勢可変型直接教 示装置 (Attachable and Pose-changable Direct Teaching device, APDT) のプロトタイプを示す．同装置は，マ ニピュレータ先端に固定される姿勢調整部と, ロック 機構により姿勢調整部に着脱される教示ハンドル部で 構成される.

[间凷において，姿勢調䬣部は教示ハンドル部の着脱 機能を行うロック機構, 教示ハンドル部のロール及び ピッチ角を調整する姿勢調整用レール及びスライダー 機構で構成される.アーチ上のレールはマニピュレー 夕の先端付近の所定の位置に予めて固定され, ピッチ 角調整用スライダー上に位置する爪タイブのロック機 構で教示ハンドル部側の接続用板をワンタッチでロッ ク又は開放する. 姿勢調整用の各スライダーは, 位置 決め操作レバーを反時計力向へ回すことで各レールか
Table 1 Parameter description

\begin{tabular}{ll}
\hline$\sum_{r}$ & Robot coordinates \\
$\sum_{h d}$ & Handle coordinates \\
$\sum_{f s}$ & Force sensor coordinates \\
$\sum_{h}$ & Hand coordinates \\
${ }_{h d}^{r} R$ & Rotation matrix between robot and handle \\
${ }_{h d}^{h d} R$ & Rotation matrix between handle and force sensor \\
${ }_{f s}{ }_{h} R$ & Rotation matrix between robot and hand \\
${ }_{h}^{h} R$ & Rotation matrix between hand and handle \\
${ }^{r} f,{ }^{r} n$ & Force/Moment according to $\sum_{r}$ \\
${ }_{f s} f,{ }^{f s} n$ & Force/Moment according to $\sum_{f s}$ \\
\hline
\end{tabular}

ら開放され，自由にスライドすることができる.した がって，教示ハンドル部のロール角はアーチ上のロー ル角調整用レール上をロール角調整用スライダーがス ライドすることで調整でき, ピッチ角はピッチ角調整用 スライダーがロール角調整用スライダーの円周をピッ 千角回転軸を中心に回転することで調整できる．姿勢 調整後は，位置決め操作レバーを時計方向に回すこと で各スライダーが全てレールに拘束され，教示ハンド ル部の姿勢角が固定される. 教示ハンドル部は， 3 ポジ ションイネーブルスイッチ, 教示ハンドル, 姿勢觕セ ンサ, カセンサで構成される. 3 ポジションイネーブル スイッチは，教示作業の許可信号を生成するものであ り，産業用ロボットの国際安全規格 ISO10218におい て装着が規定されている. 姿勢角センサ (InertiaCube3, InterSense 社) は，教示ハンドル部を姿勢角調整部に装 着した際又は装着後姿勢角調整を行った場合に，ハン ドル及び力センサの姿勢角を直接に計測するために用 いられる. 最後に, 6 軸力覚センサ (Nitta 製) は直接 教示の追従制御に用いられる作業者の教示力を検出す る. 開発した教示ハンドル部は，直接教示制御に必要 な情報を生成するスイッチ及びセンサ要素がモジュー ル化されているのが特改的である。これにより，教示 ハンドル部の着脱時の空間的制約が緩和され，幅広い 範囲における姿勢調整機能が実現できる他，直接教示 システム全体のモジュール化も容易となる.

図 3 に開発したAPDTをSP02 のマニピュレータ先 端へ導入し，ハンドル操作を行う様子を示す．同四か ら，教示ハンドル部の䒾着，ロール姿勢角調整，ピッ 千姿勢角調整，位置決め，教示ハンドル部の取り外し 等の一連の動作が確認できる.

\section{3. 教示情報の取得及び評価検証}

3.1 操作力の座標変換 マニピュレータ先端が 作業者の操作力に忠実に追従するためには, 操作力が 


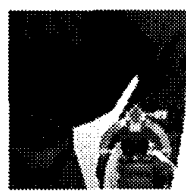

(a) Initial

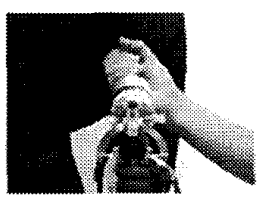

(g) Pitch rot.(-)

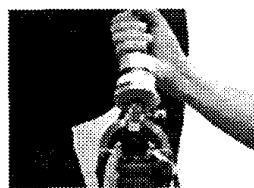

(b) Mounting

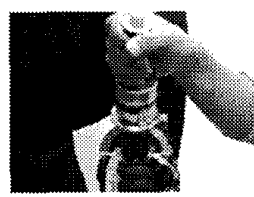

(h) Pitch rot.(+)

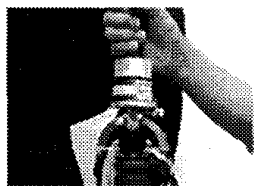

(c) Mounted

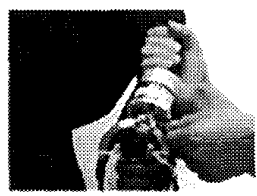

(i) Positioning

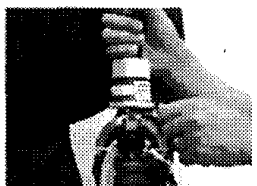

(d) Releasing

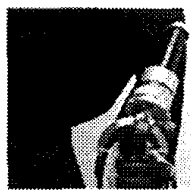

(j) Positioned

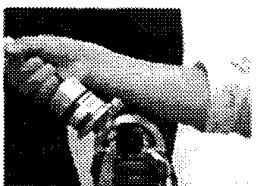

(e) Roll rot.(-)

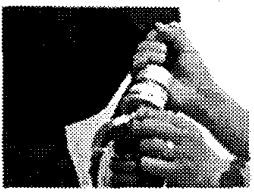

(k) Dismounting

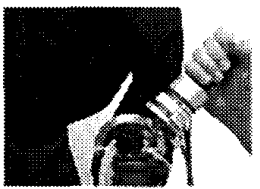

(f) Roll rot.(+)

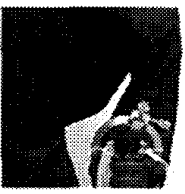

(1) Dismounted

Fig. 3 A series of motion of introduction and operation of APDT to SP02 (mounting, pose adjusting, and dismounting)

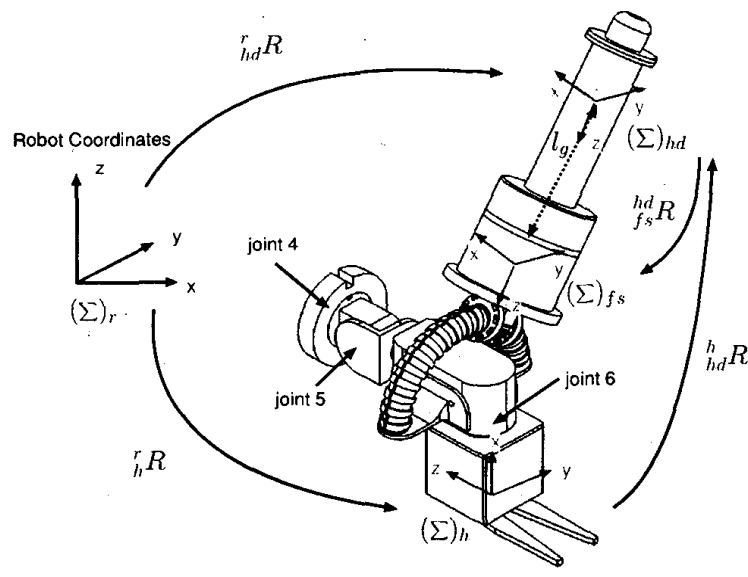

Fig. 4 Robot end-effector model with an APDT

基準座標系へ正しく変換される必要がある，そのため には，マニピュレータ先端運動時において，力センサ 姿勢の正確な計测及びロボット座標系への正しい变換 が重要である。

APDT を装着したマニピュレータ先端の幾何学モデ ルを図 4 に，各記号の定義を表 1 に示す。本稿では, 操作力追従制御力法として, 可変コンプライアンス制 御法を用いる(12). コンプライアンス制御における手先 先端の運動力程式は,

$$
M \ddot{x}_{d}+D \dot{x}_{d}={ }^{r} F
$$

であり， $M, D$ はそれぞれ手先先端の望ましい慣性及 び粘性を表す．操作力のロボット座標系での表現 ${ }^{r} F$ は,

$$
{ }^{r} F=\left[\begin{array}{c}
r_{f} \\
r_{n}
\end{array}\right]=\left[\begin{array}{cc}
{ }^{r} R & 0 \\
I & { }_{f s} R
\end{array}\right]\left[\begin{array}{c}
f_{s} f \\
{ }^{f s} n
\end{array}\right]
$$

であり,ここで,

$$
{ }_{f s}^{r} R={ }_{h d}^{r} R{ }_{f s}^{h d} R
$$

Iは単位行例である。なお, ロボット座標系と力セン サ座標系は同じ原点を持つとし，ハンドル座標系と力 センサ座標系は教示ハンドル部に固定されているので ${ }_{f s}^{h d} R$ は不変である. S したがって, ハンドルの回転行 列 ${ }_{h d}^{r} R$ を常時求めることができれば, 式 (2)から ${ }^{r} F$ を 計算し, 教示追従制御への入力として用いることがで きる.

マニピュレータ先端が動作中の ${ }_{h d}^{r} R$ は, 教示ハンド ル部の姿勢角センサのみ, 又は, 教示ハンドル部装着 時の初期姿勢角とマニピュレータの内界センサを併用 して求めることができる. 前者は, 教示追従制御のリ アルタイム性を保証するために，姿勢角センサの姿勢 角検出サイクルタイムがロボットの教示制御サイクル タイムより短い場合に有効な方法である.これに対し て後者は, 教示情報検出サイクルタイムがロボットの 制御サイクルタイムより長いか, 教示装置がリアルタ イム通信機能を装備していない場合に有効である. 本 稿では, (1) ハンドル姿勢検出センサの検出サイクル タイムが長い (最短 $10[\mathrm{~ms}])$, (2) 教示情報生成装䈯の リアルタイム通信機能の不備, (3) 連続言十測時の測定 エラー (特に磁気センサ) の発生可能性等の理由によ り, 後者を用いて教示追従制御時の ${ }_{h d}^{r} R$ をリアルタイ ムで計测する。

マニピュレータ先端部の幾何学的条件から,

$$
{ }_{h d}^{r} R={ }_{h}^{r} R{ }_{h d}^{h} R
$$

であり, ${ }_{h}^{r} R$ はロボット側から計測できるので ${ }_{h d}^{h} R$ が既 知であれば ${ }_{h d}^{r} R$ が計算できる. ${ }_{h d}^{h} R$ はハンドルを先端 に取り付けた時の初期姿勢角情報と先端の姿勢情報か ら次式で求めることができる.

$$
{ }_{h d}^{h} R=\left({ }_{h}^{r} R_{i}\right)^{-1}{ }_{h d}^{r} R_{i}={ }_{r}^{h} R_{i}{ }_{h d}^{r} R_{i}
$$

ここで, ${ }_{h}^{r} R_{i}$ :ハンドル装着時のハンドのロボット座標 系における姿勢角, ${ }_{h d}^{r} R_{i}$ : ハンドル装着時のハンドル 


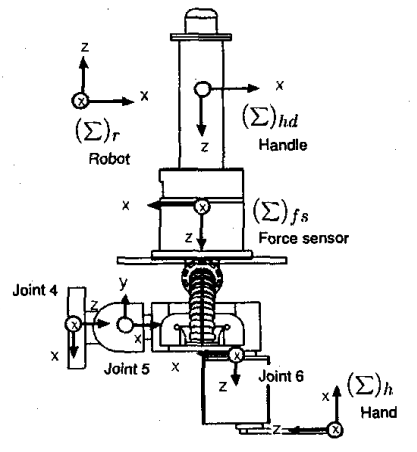

Fig. 5 Relation of the coordinates on an end-effector

のロボット座標系における姿勢角である. 式 (4), 式 (5) から,

$$
{ }_{h d}^{r} R={ }_{h}^{r} R_{r}^{h} R_{i}{ }_{h d}^{r} R_{i}
$$

の関倸が得られる. 式 (6) を用いることでロボットの 動作中にハンドルの姿勢角をリアルタイムで計測する ことができ，その情報を用いて操作力を追従制御部へ 正しく変換することができる.

3.2 初期姿勢角計測評価 手先先端の様々な妿 勢において, 教示ハンドル部の装着時の力センサの姿 勢角計测精度を調べるための評価実娩を行う。評価は, ロボット座標系において，ロボット側の内界センサに よる順運動学計算を用いた場合と姿勢角センサを用 いた場合の力センサ座標系の姿勢角を比較することで 行う.

図 5 に評価実験における SP02 の手先先端と APDT との軸間関係を示す。まず，ロボットの内界センサを 用いた順運動学計算において，力センサ座標系のロ ボット座標系への回転行列は,

$$
{ }_{f s}^{r} R={ }_{h}^{r} R_{f s}^{h} R
$$

となる，また，姿勢角センサを用いた力センサ座標系 のロボット座標系への回転行列は次式で表すことがで きる.

$$
{ }_{f s}^{r} R={ }_{h d}^{r} R{ }_{f s}^{h d} R
$$

ここで,

$$
{ }_{h d}^{r} R=\operatorname{Rot}(X, \pi) \operatorname{Rot}\left(Z, \theta_{w}\right) \operatorname{Rot}\left(Y, \theta_{p}\right) \operatorname{Rot}\left(X, \theta_{r}\right)
$$

であり， $\theta_{r}, \theta_{p}, \theta_{w}$ は姿勢角センサからの姿勢角情報で ある. 式 (7) と式 (8) から求めた力センサの回転行列 から各々姿勢角を計算し，比較することで，同装置の 姿勢解計測精度を評価することができる。

力センサ座標系の姿勢計測検証実験方法を以下に述 ベる．まず，教示ハンドル部を初期状態で困 5 のよう

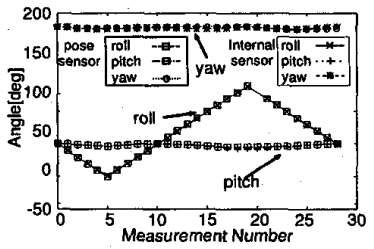

(a) Roll motion

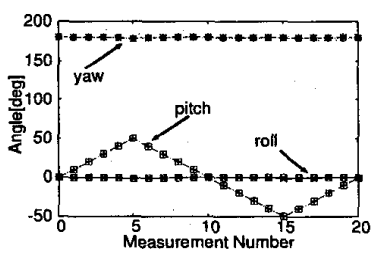

(c) Pitch motion

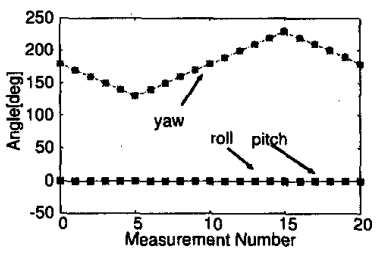

(e) Yaw motion

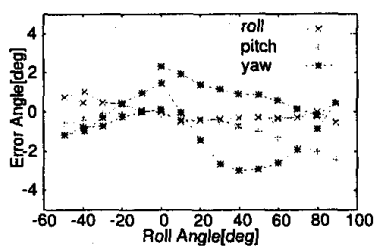

(b) Error(roll motion)

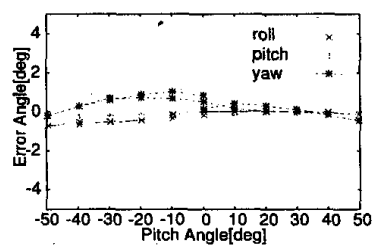

(d) Error(pitch motion)

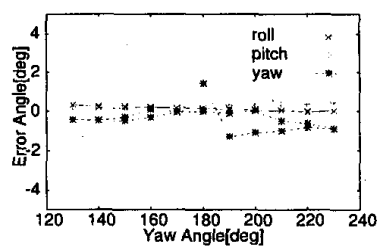

(f) Error(yaw motion)
Fig. 6 Measurement varification of a posture sensor

に手首の第 5 軸， 6 軸の間に装着する．その後， SP02 の動作 API を用いて, 手首先端座標系(第6 軸座標系) をロール, ピッチ，ヨー方向に回転する，その都度，口 ボット運動学計算関数から求めた力センサ座標系 (式 (7)) と姿勢角センサを用いた力センサ座標系 (式 (8)) の姿勢角を求め, 両方を比較する.

図6に手先先端のロール，ピッチ，ヨー方向の独立 回転の場合の実験データを示す．同図 (a)(c)(e) は，各 実験において，両方法で計測した力センサ座標系の姿 勢角がほぼ一致していることを表しており，(b)(d)(f) は，その差分値がロール，ピッチ角に関しては -1 か ら 2 度内, ヨ一角の場合は -3 から 3 度であることを 示している. ヨ一角の差分値が大きい理由としては, モータの磁場の影響を無くすために姿勢角センサのコ ンパス機能を OFFにしており, ジャイロセンサの蓄 皘愦差の修正がなされないのが考えられる.

以上の評価実験から，任意の姿勢のマニピュレータ 先端に直接教示ハンドル部を装着する際，内蔵の姿勢 角センサを用いて数度程度の䛊差範囲内で力センサの 姿勢計測が可能であることが確認できた。

\section{4. 直接教示検証実験}

本章では, SP02 への直接教示作業において, 直接 教示性能及び作業者の作業姿勢に対する APDT の有効 性を検証する実験を行う．図７に実験装置のシステム 


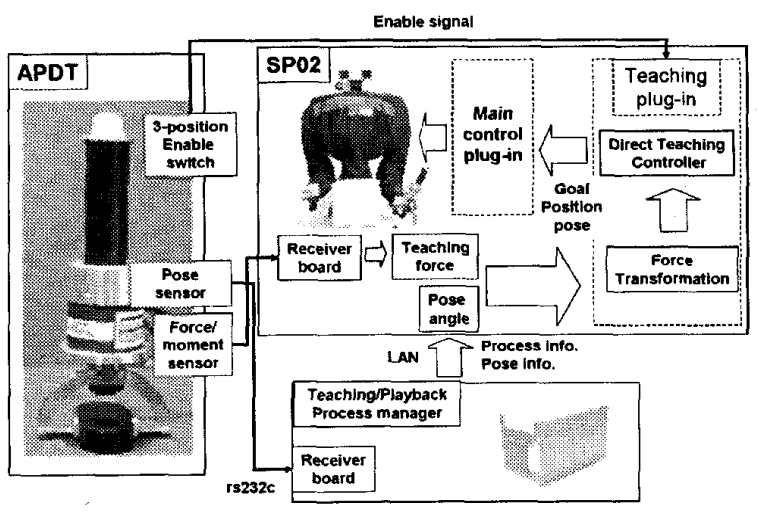

Fig. 7 Experimental setup

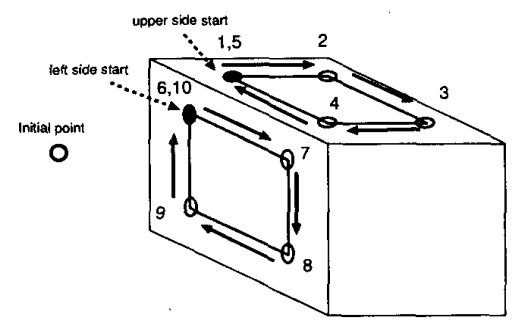

Fig. 8 Experimental target for direct teaching varification

構成汹を示す，间困において，APDT の姿勢角情報は 亘接教示及び再生工程を管理するシステムに取り込ま れ，工程管理情報と一緒に LAN を通して SP02 の制 御システムに送られる. 力覚センサの操作力の生デー タはSP02 の制御システムへ直接に取り込まれ，その 後姿勢角情報によりロボット座標系での操作力に変換 された後, 直接教示制御器へ入力される．最終的に, 真接教示制御 plug-in は直接教示制御器からの手先先 端の日標位置及び姿勢を SP02 の主制御 plug-in へ出力 し, 主制御 plug-in はその情報を基に各サーボを制御 し, SP02 の教示追従動作を奏行する.

4.1 教示ハンドルの姿勢角誤差の影響 教示ハ ンドルの姿勢解のずれが教示性能に与える影響を調べ る実験を行う。検証実験では，教示ハンドル部を困 5 のように初期セット後, 図 8 に示す教示ターゲットの 上面正方形 4 点 (各辺長 $25 \mathrm{~cm}$ ) を一周する教示作業を 教示ハンドル部の努勢角誤差無し (CASE 1), 唄差小 (CASE 2), 俱差大 (CASE 3) の三つの方法で央行し, 教示操作性能について検討する.CASE 1 では, 教示 ハンドル部を初期努勢の状態で操作し，教示を行う. この場合では, 教示ハンドル部の姿勢をロボットの運 動学計算により誤差なく検出する. CASE 2 の場合は, 姿勢調整機構を用いて教示ハンドル部を初期姿勢か ら変更するが，変更された姿勢角は努勢角センサによ

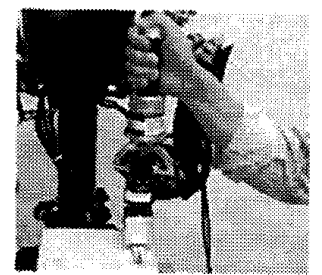

(a) CASE 1

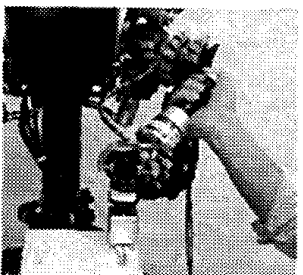

(b) CASE 2,3

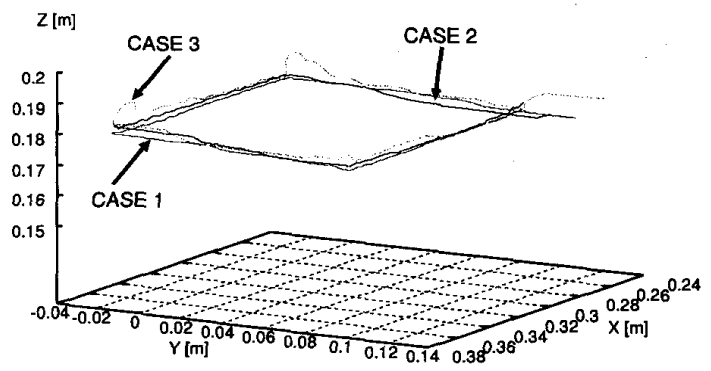

(c) total comparison

Fig. 9 Direct teaching performance according to the pose error of the teaching handle part

り䛊差を持って計測される，CASE 3 の場合は，姿勢 調整機構を用いて教示ハンドル部の初期姿勢を変更す るが, 姿勢角センサでの姿勢角計測は行わない. した がって，この場合は幾何学条件から求めた姿勢角と調 整後の姿勢角に大きなズレが存在することになる. 教 示操作は, 可能な限りロボットの手先先端が教示タ一 ゲットの四解形のラインに沿うように教ホハンドル部 の操作を行うようにした.

図 9 に各実験における教示ハンドル部の初期妿勢, 及び各教示追従動作におけるロボット手先先端の軌跡 を示す. 各実験における教示ハンドル部初期姿勢角は， CASE 1 の場合, ロール 0 度, ピッチ 0 度, ヨー 20 度 であり (困 9(a)), CASE 2, CASE 3 の場合は, ロール -50 度, ピッチ 34 度, ヨー - 19 度である (困 9(b)). 困 9(c)において，CASE 1 及び CASE 2 は手先先端の 教示追従運動性能がよく, 追従軌跡が滑らかな四角形 を描いている。これに対し, CASE 3 の場合は, 四角 形の辺部分の教示においては比較的良い追従性能を見 せるが, 方向が大きく変わる各頂点において軌跡に大 きな凹凸が発生している。これは，一方向の運動に対 しては人間側が努勢角の俱差分をうまく補正してハン ドル操作を行っているが, 角の部分では運動方向が大 きく変わるので人間側の補正がうまく行われないため である.

これらの実験結果から，ある程度の俱差を含む姿勢 角センサを用いた場合でも，作業者の意四に近い教示 追従性能を実現できることが確認できた。しかし，䛊 


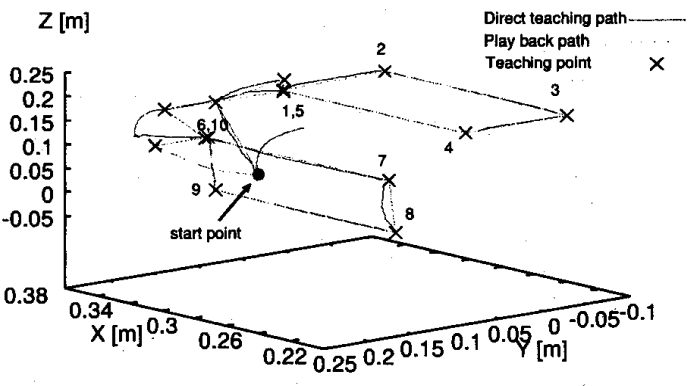

(a) Path profile of an end-effector

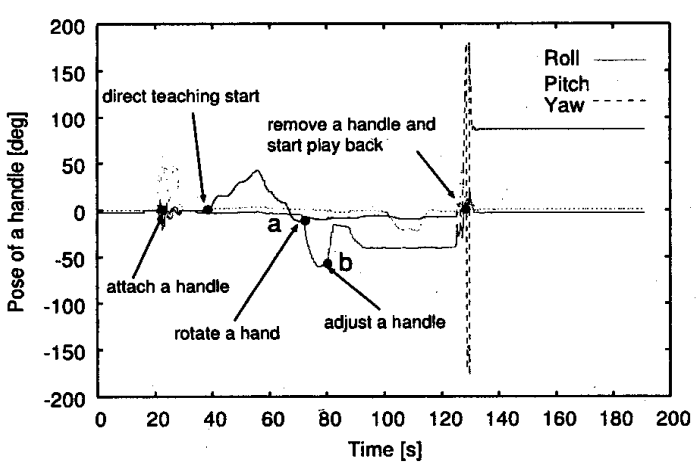

(b) Pose profile of a teaching handle

Fig. 10 Direct teaching and playback experimental result using APDT

差角が大きくなった場合は，軌道によっては作業者の 補正機能が十分に動かず，追従動作が乱れることにな る.したがって，姿勢角度俱差が教示追従性能に及ぼ す影幚をより詳しく調べることで，ハンドル姿勢調整 角分觶能の選定など教示システムをより最適に設計す ることができると考えられる.

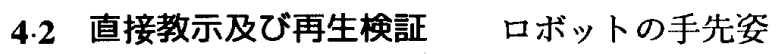
勢が大きく変化する教示作業において，APDTを用い た亩接教示及び教示後再生の一連の教示作業工程を実 行し, 问装置の教示作業遂行性能, 及び作業者の教示 姿勢を評価する。

実験では，困 8 の教ボターグットの上面 4 点と側 面 4 点の教示を行う. 各教示点の情報は作業者が手元 の操作スイッチ盤の「教示情報取得ボタン」を押すこ とで亡程管理システムに入力され, 教示後, 再生へス イッチの切替えにより SP02 は入力された教示点を再 現する. 被験者となる作業者には, 各点を移動する際 に可能な限り各点を結ぶ辺に洛って移動するようにし， また，側面の教示においては，負担のかからない姿勢 で作業ができるようにハンドル部姿勢を変更するよう に指示した。被娩者 (男性, 1 名) は, APDT の操作方 法を㫮得しており，検証用の教示工程が滑らかに契行 できるように事前に十分な練酱を行っている.
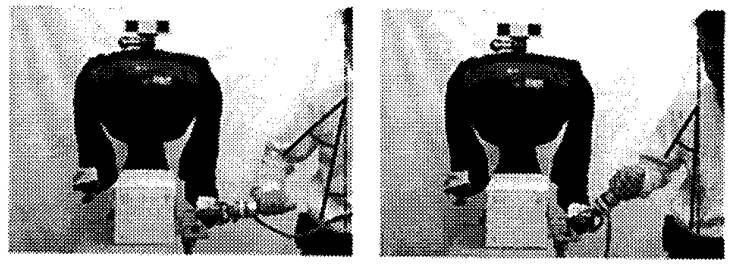

(a) Case of without adjusting the (b) Case of adjusting the handle handle pose pose

Fig. 12 Pose of an operator in the leftside direct teaching

図 10 に教示及び再生作業の実験結果を，図 11 に 教示中の作業者及びロボットの一連の動作様子をキャ プチャした写真を示す．困 10(a) は教示及び再生時の 手先先端の軌跡を表しており，教示時の先端軌跡が上 面及び側面四角形の形状を凹凸なく描いていることが 分かる. また，教示再生時のハンドの軌跡も教示ポイ ントを忠実に実現していることから，教示が正常に行 われていることが確認できる. 困 10(b) は教示作業中 の教示ハンドル部の姿勢角データである．同困におい て, 上面教示から側面教示に作業工程を变更する際, 作業者は $a$ 時点から手先先端と一緒にハンドル部の ロール角をほぼー70[deg] まで回転している，その後, 不適切な姿勢を直すために, $b$ 時点からハンドル部の みロール角を約 $-10[\mathrm{deg}]$ に調整した後，教示作業を 行っていることが確認できる.

図 12 は側面教示作業におけるハンドル姿勢角調整 なしと調整ありの場合の作業者の奖勢である。同図か ら分かるように, APDT のハンドル姿勢角の調整によ り时関節や腰関節の負担が軽くなっており，長時間の 教示作業時の不適切な姿勢に起因するリスクの低減が 期待できる.しかし，ハンドル姿勢角調整無しの場合 についても同教示作業を実施した結果, 努勢角調整あ りの場合と比較して教示時間や精度に大きな差はない ことが確認された.これは, 今回行った教示作業が単 純で所要時間も短かったためであり，より長時間の教 示作業における評価が必要であると考えられる.

\section{5. おわりに}

本稿では, 多自由度マニピュレータの直接教示作業 において，教示作業効率の向上を目的とした高い操作 性を提供する姿勢可变型直接教示装置を提案した。同 装萓を用いた操作性検証実験により，作業者が多自由 度マニピュレータの先端焱勢に影響されることなく， 必要な時に教示ハンドル部を装着し，自然な姿勢で直 接教示作業を実行できることが確認できた．本稿では， 提案装置の教示作業遂行性能及び作業者の教示姿勢の 


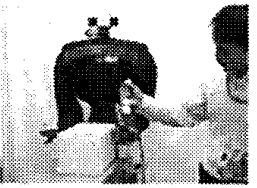

(a) Mounting

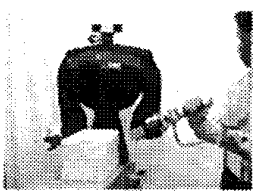

(g) Rotating

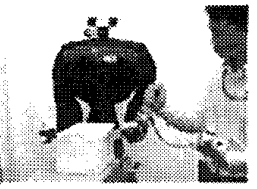

(m) 10th point

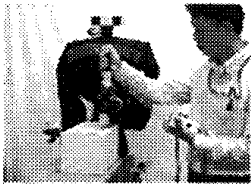

(b) 1st point

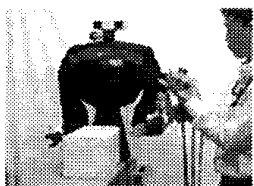

(h) Pose change

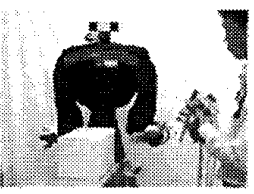

(n) Dismounting

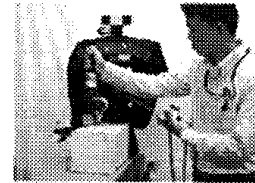

(c) 2nd point

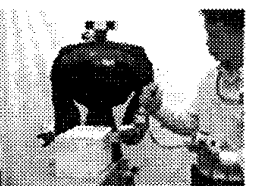

(i) 6th point

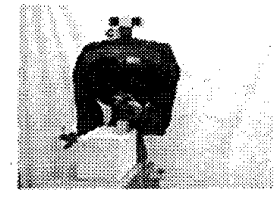

(o) 1 st point...

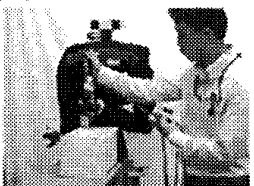

(d) 3rd point

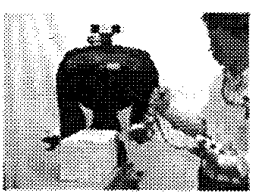

(j) 7th point

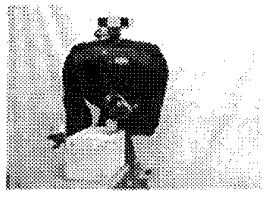

(p) 5th point

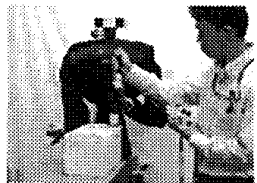

(e) 4th point

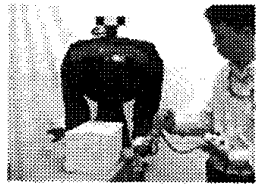

(k) 8th point

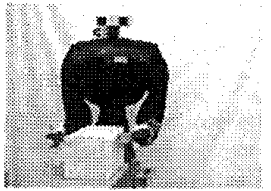

(q) 6th point...

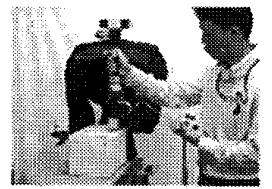

(f) 5 th point

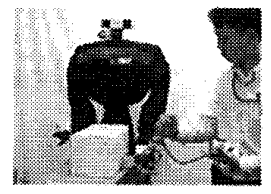

(1) 9 th point

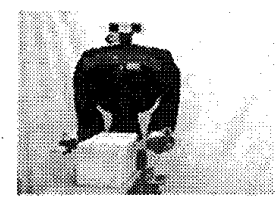

(r) 10 th point

Fig. 11 Screenshot of a series of motion of direct teaching and playback

定性的評価に留まっている.

今後, 㷌時間の教示が必要な教示作業において, 作 業者の疲学蓄積による教示時間及び教示精度の評価を 行い，同装惪の操作性の優位性をより明確にする予定 である。

\section{文献}

(1) Yukihiro Nakamura, Kenichi Arakawa: Teaching via Multimodal Communication, Journal of Robotics Society of Japan, Vol.17, No.2, (1999), pp.166-169.

(2) Tamio Arai, Toshiyuki Itoko, Hidetoshi Yago, Visual Robot Programming System, Journal of Robotics Society of Japan, Vol.17, No.2, (1999), 186-189.

(3) Yoichi Nagao, Kazuhiko Onoue, Teaching Method and Open Architecture Controller for Industrial Robots, Journal of Robotics Society of Japan, Vol.18, No.4, (2000), pp.486-490.

(4) Yoshihiro Mochizuki, Takashi Matsui, Direct Teaching Method for Hybrid Control Applying Impedance Control, Journal of Robotics Society of Japan, Vol.12, No.2, (1994), pp.328-334.

(5) ISO 12100-1:2003 : Safety of machinery- Basic concepts, general principles for design (2003)

(6) Shin-yo Muto, Ken-ichiro Shimokura, Teaching and Control of Robot Contour-Tracking Using Contact Point Detection, Journal of Robotics Society of Japan, Vol.15, No.5, (1997), pp.744-751.

(7) Yaskawa Electric Co., Teaching Device of Robot, Tokukai, H8-216074, (1996).

(8) Yaskawa Electric Co., Handle for Direct Teaching, Tokukai, H8-276387, (1996).

(9) Fumiyo Saijo, Posture and Motion. Working Postures and Physical Load, Rigakuryoho, Vol.10, No.3, (1995), pp.127-134.
(10) T.Ogure, Y.Nakabo, S.Jeong, Y.Yamada: Hazard Analysis of an Industrial Upper-body Humanoid, Industrial Robot, No.35, Vol.5, 469/475 (2009).

(11) AIST, Pose Changable Direct Teaching Module, Tokugan, 2009-116141, (2009).

(12) Y.Yamada, H.konosu: Proposal If Skill-Assist: A system of Assisting System for Human Workers by Reflecting Their Skills in Positioning Tasks, Proceedings of IEEE International Conference on Systems, Man and Cybernetics, IV11-16 (1999) 